\title{
Publisher Correction: Tear resistance of soft collagenous tissues
}

\author{
Kevin Bircher ${ }^{1}$, Manuel Zündel ${ }^{1}$, Marco Pensalfini ${ }^{1}$, Alexander E. Ehret (1D ${ }^{1,2}$ \& Edoardo Mazza ${ }^{1,2}$
}

Correction to: Nature Communications https://doi.org/10.1038/ss41467-019-08723-y, published online 15 February 2019.

The original version of this Article contained errors in the third and fourth sentences of the 'Computational material models' section of the "Methods", which incorrectly read 'The model is generated by randomly placing cross-links at a density of $\rho_{\mathrm{c}}=0.075 \mathrm{~m}$ " specified domain ${ }^{31}$. Four connectors representing the fibers are defined for each cross-link based on a random-weighted sampling process with uniform orientation distribution and a distribution in length resembling the shape of a Poisson distribution with mean $L_{\mathrm{c}}=10 \mathrm{~m}$, if not specified otherwise.' The correct version states ' $\rho_{\mathrm{c}}=0.075 \mu \mathrm{m}^{-2}$ ' in place of ' $\rho_{\mathrm{c}}=0.075 \mathrm{~m}^{-2}$ ' and ' $L_{\mathrm{c}}=10 \mu \mathrm{m}$ ' rather than ' $L_{\mathrm{c}}=10 \mathrm{~m}$ '.

The second and third sentences of the fourth paragraph of the same section originally incorrectly read 'The network was generated by seeding cross-links at a density $\rho_{\mathrm{c}}=5 \times 10^{-4} \mathrm{~m}^{-3}$ within the domain of a representative volume element (RVE) of the membrane. Fibers were then defined by four random connections between these crosslinks, uniformly distributed within the membrane plane and sampled from a distribution ${ }^{27} p(l, \varphi)$ leading to a von-Mises distributed out-of-plane angle $\varphi$, controlled by the concentration parameter $\beta=3$, and Poisson-like distributed fiber lengths with mean $L_{\mathrm{c}}=10 \mathrm{~m}$.' The correct version states ' $\rho_{\mathrm{c}}=5 \times 10^{-4} \mu \mathrm{m}^{-3}$ ' instead of ' $\rho_{\mathrm{c}}=5 \times 10^{-4} \mathrm{~m}^{-3}$ ', and ' $L_{\mathrm{c}}=10 \mu \mathrm{m}$ ' instead of ' $L_{\mathrm{c}}=10 \mathrm{~m}$ '.

This has been corrected in both the PDF and HTML versions of the Article.

Published online: 30 May 2019

\begin{abstract}
(c) Open Access This article is licensed under a Creative Commons Attribution 4.0 International License, which permits use, sharing, adaptation, distribution and reproduction in any medium or format, as long as you give appropriate credit to the original author(s) and the source, provide a link to the Creative Commons license, and indicate if changes were made. The images or other third party material in this article are included in the article's Creative Commons license, unless indicated otherwise in a credit line to the material. If material is not included in the article's Creative Commons license and your intended use is not permitted by statutory regulation or exceeds the permitted use, you will need to obtain permission directly from the copyright holder. To view a copy of this license, visit http://creativecommons.org/licenses/by/4.0/.
\end{abstract}

(C) The Author(s) 2019

\footnotetext{
${ }^{1}$ ETH Zurich, Institute for Mechanical Systems, 8092 Zurich, Switzerland. ${ }^{2}$ Empa, Swiss Federal Laboratories for Materials Science and Technology, 8600 Dubendorf, Switzerland. Correspondence and requests for materials should be addressed to A.E.E. (email: alexander.ehret@empa.ch)

or to E.M. (email: mazza@imes.mavt.ethz.ch)
} 